\title{
Analisis Pengaruh Marketing Mix Berbasis Media Sosial Untuk Meningkatkan Omzet pada Bual-Bual Cafe
}

\author{
Ismu Kusumanto ${ }^{1}$, Eka Khairika ${ }^{2}$ \\ ${ }^{1,2}$ Jurusan Teknik Industri, Fakultas Sains dan Teknologi, UIN Sultan Syarif Kasim Riau \\ J1. HR. Soebrantas No. 155 Simpang Baru, Panam, Pekanbaru, 28293 \\ Email : ismu uin@yahoo.co.id
}

\begin{abstract}
ABSTRAK
Keberadaan konsumen merupakan faktor penentu keberhasilan suatu usaha, dimana kekurangan konsumen berdampaklah pada omzet. Kondisi ini terjadi pada Bual-Bual Cafe yang tidak dapat mencapai target yang seharusnya dicapai untuk menutupi biaya operasional dan meraih keuntungan. Maka perlu dilakukan strategi pemasaran, salah satunya dengan menggunakan strategi marketing mix berbasis media sosial untuk meningkatkan Omzet Bual-Bual Cafe. Metode yang digunakan yaitu Regresi Linier Berganda, dimana didapatkan adanya pengaruh keseluruhan variabel bebas terhadap variabel terikat sehingga strategi marketing menggunakan media online menjadi salah satu alternative untuk meningkatkan omzet Bual-Bual Cafe. Variabel bebas Produk memiliki pengaruh paling tinggi dari keempat variabelyang diteliti.
\end{abstract}

Kata Kunci: Marketing Mix, Omzet, Regresi Berganda, Uji F dan Uji t.

\section{Pendahuluan}

\section{Latar Belakang}

Bual-Bual Cafe berdiri sejak 20 Januari 2016 ini memiliki masalah utama pada kurangnya jumlah konsumen sehingga mempengaruhi pendapatan usaha. Konsumen ramai hanya pada malam Sabtu dan malam Minggu, sedangkan dimalam-malam lainnya masih sangat sepi. Target pendapatan yang seharusnya dicapai untuk menutupi biaya operasional tidak dapat terpenuhi. Demikian pula BEP (Break Even Point) tidak dapat terpenuhi sehingga Bual-Bual Café merugi.

Untuk meningkatkan omzet Bual-Bual Cafe maka perlu dilakukan strategi pemasaran dengan menggunakan Marketing Mix Berbasis Media Sosial sehingga mampu meningkatkan omzet Bual-Bual Cafe".

\section{Landasan Teori}

\section{Pengertian Pemasaran}

Kebanyakan orang telah salah mengartikan dan menganggap pemasaran sama dengan penjualan. Penjualan merupakan bagian pemasaran dan menjadi fungsi puncak pemasaran. Sementara fungsi pemasaran lainnya adalah mengidentifikasikan kebutuhan konsumen, mengembangkan produk yang tepat, menetapkan harga, melaksanakan distribusi dan promosi secara efektif serta lain sebagainya.

Pemasaran telah dipandang sebagai unsur penting dalam mendirikan perusahaan. Dengan lingkungan dunia usaha yang semakin kompetitif dan sifat pasar berubah dari sales market menjadi buyer market atau kekuatan pasar ditangan konsumen, sehingga kegiatan perusahaan menjadi orientasi konsumen (Hayani, 2012).

Pemasaran tidak terbatas pada dunia bisnis saja, karena sebenarnya setiap hubungan antar individu dan antar organisasi yang melibatkan proses pertukaran adalah kegiatan pemasaran (Kotler, 1994 dikutip oleh Hayani, 2012).

\section{Marketing Mix (Bauran Pemasaran)}

'Marketing mix is the set of marketing tools that the firm uses to pursue its marketing objektives in the market' (Hayani, 2012). Yang kurang lebih memiliki arti bauran pemasaran adalah kumpulan dari variabel-variabel pemasaran yang dapat dikendalikan yang digunakan oleh suatu badan usaha yang untuk mencapai tujuan pemasaran dalam pasar sasaran.

Menurut Stanton (1978 dikutip oleh Hayani, 2012), bauran pemasaran (marketing mix) adalah kombinasi dari 4 variabel atau kegiatan yang merupakan inti dari sistem pemasaran perusahaan yaitu produk, harga, kegiatan promosi dan sistem distribusi. Atau menurut McCarthy 4 
(empat) faktor disebut dengan the four $\mathrm{P}$ : Product, Price, Place, And Promotion.

\section{Definisi dan Peran Media Sosial}

Kemajuan teknologi telah memudahkan untuk mengekspresikan diri dan mendapatkan berita dengan cepat melalui platform media sosial. Media social telah menjadi gaya hidup dan kebutuhan, baik untuk komunikasi pribadi, promosi diri, atau kegiatan marketing.

Media social saat ini telah menjadi media yang efektif dalam pemasaran dan penjualan. Bagi pihak penjual, promosi dan transaksi elektronik melalui media sosial akan membantu untuk memperluas daerah pemasaran produk yang akan dijualnya, sedangkan bagi pembeli, akan mempermudah mendapatkan dan membandingkan informasi tentang produk yang akan dibelinya (Setiawati, 2014).

Selain memberikan banyak sekali peluang dan keuntungan, media sosial memiliki beberapa resiko yang akan dihadapi oleh si pemilik bisnis online. Bisnis secara online, memang jauh lebih mudah dan murah dibanding dengan membuka toko biasa, ditinjau dari segi modal bisnis ini dapat menghemat sebagian dana sewa lahan atau sewa toko, namun resiko yang ada juga lebih berat, kerusakan sistem komputer karena virus, pencurian kode pasword, tentu akan menimbulkan kerugian yang jauh lebih besar. Berkembangnya teknologi dalam mengakses pembayaran juga sangat membantu, namun dalam bisnis online ini juga beresiko ditipu atau bahkan tidak dibayar (Setiawati, 2014).

Menurut Setiawati dan Mashuri (2014), Pengembangan strategi pemasaran elektronik atau e-marketing diperlukan pada proses transaksi bisnis online. Berikut adalah lima strategi untuk mengembangkan strategi pemasaran bisnis online

1. Mengetahui pangsa / segmentasi pasar Consument)

Strategi pemasaran anda tidak akan pernah sukses jika tidak memiliki khalayak yang jelas. Sebelum anda menghabiskan uang pada pemasaran, sangat perlu untuk mencari tahu target pasar anda terlebih dahulu.

2. Menetapkan tujuan.

Tentukan apa yang dicari untuk mendapatkan benefit dari pemasaran bisnis online.

3. Menetapkan anggaran (Capital)

Hal yang baik tentang pemasaran online adalah ketika berhasil, pada anggaran yang ketat dengan banyaknya platform yang tersedia tanpa biaya.

4. Merek sendiri.

Tentukan sendiri merek produk anda terpisah dari kompetitor. Ada ribuan perusahaan mencoba untuk menjual produk di Internet. Dengan demikian, perlu membuat merek yang tak terlupakan.

5. Kembangkan relasi.

Membina hubungan antara produsen dan konsumen dengan cara berkomunikasi yang dilakukan secara terus menerus memunculkan kedekatan. Kedekatan yang dibangun secara tidak langsung akan menimbulkan kepercayaan, sehingga konsumen tidak takut untuk membeli barang secara online.

\section{Facebook Marketing}

Facebook merupakan situs yang layanan utamanya adalah layanan jejaring sosial (Barnes dikutip oleh Cahyono, 2011). Facebook memiliki kelebihan-kelebihan sebagai berikut :

\section{Internet booming}

Internet semakin mudah diakses dan pengguna internet semakin meningkat.

2. Facebook termasuk website yang paling sering dikunjungi

Indonesia menempati peringkat kedua terbanyak pengguna facebook, dengan jumlah pengguna 38.164 .520 orang. Sedangkan di Indonesia fecebook menempati rating pertama mengalahkan google sebagai website yang paling sering dikunjungi.

3. Facebook menyediakan fungsi informasi Facebook menyediakan kolom untuk mengisi berbagai informasi pemakainya, seperti umur, lokasi, hobi, kegiatan dan informasi lain yang sangat dibutuhkan untuk menetukan segmentasi pasar dalam aktivitas marketing.

4. Fokus segmentasi pasar

Dengan fecebook dapat dilakukan penyaringan target pasar dengan tepat sasaran berdasarkan informasi yang disajikan penggunanya.

5. Mudah diakses

Facebook dapat diakses melalui jaringan internet setiap saat, dimana saja dan hanya membutuhkan sambungan internet untuk dapat masuk ke situs facebook.

6. Kemudahan berkomunikasi

Facebook menyediakan fungsi komunikasi, yaitufungsi pesan (message), dan obrolan (chat). Dengan demikian informasi dapat dilakukan secara lebih cepat dan mudah.

7. Adanya zero time feedback

Umpan balik dapat berupa kritik dan saran dapat disampaikan dengan cepat. Pemasar dapat menaggapi pesan dari konsumen secara lansung sehingga terjadi interaksi.

8. Selalu terhubung

Facebook sebagai alat komunikasi dengan dunia bisnis, sehingga bisnis akan terpelihara dengan baik sepanjang masa. 
9. Law budget, high impact

Menggunakan facebook $100 \%$ gratis sehingga banyak penghematan bisa dilakukan.

Sedangkan menurut Mirratin (2014), terdapat kekurangan facebookdiantaranya adalah sebagai berikut:

1. Penyalahgunaan privasi pelanggan

2. Belum semua masyarakat sadar internet

3. Sulit melakukan pengawasan dan pengendalian

4. Belum bisa menjangkau semua kalangan pasar

5. Adanya potensi acaman penipuan kejahatan

6. Muncul berbagi gangguan meresahkan penggunanya

\section{Keterkaitan Marketing Mix dengan Facebook}

Facebook memiliki keterkaitan dengan variabel marketing mix yang diantaranya Promosi, Harga dan Tempat, yaitu sebagai berikut:

1. Promosi

Promosi adalah hal yang sangat berkaitan dengan facebook. Bentuk promosi ada dua, yaitu pasif dan aktif. Contoh pasif adalah penyebaran brosur, spanduk dan lain-lain, sedangkan contoh aktif diantaranya promosi secara langsung. Akan tetapi dengan adanya facebook maka pemasar tidak perlu membuat spanduk dan melakukan pertemuan secara langsung yang banyak menguras tenaga dan biaya.

2. Harga

Terdapat beberapa faktor yang mempengaruhi peningkatan harga produk, diantaranya biaya produksi, biaya bahan baku, dan biaya promosi. Facebook mampu menurunkan harga produk disebabkan biaya promosi yang relative murah, biaya pemesanan bahan baku dan lain-lain. Maka dari itu bisa dikatakan media sosial berupa facebook mempunyai keterkaitan dengan harga.

3. Tempat

Tempat mempunyai keterkaitan dengan facebook, dimana tempat usaha bisa dimana saja karena konsumen tak perlu datang ketempat lokasi penjualan, konsumen bisa memesan produk secara online dan diantar langsung kepada konsumennya.

4. Produk

Produk mempunyai keterkaitan dengan facebook karena produk perlu ditampilkan dalam facebook.

\section{Metodologi Penelitian}

Penentuan Populasi dan Sampel
Menurut Sugiyono (2005 dikutip oleh Puryono, 2014), populasi adalah wilayah generalisasi yang terdiri dari objek dan subjek yang menjadi kuantitas dan karakteristik tertentu yang diterapkan oleh peneliti untuk dipelajari dan kemudian ditarik kesimpulan.

Sampel adalah bagian dari jumlah pupulasi yang ada, sampel adalah semacam miniatur dari populasinya. Dalam pengambilan sampel untuk sebuah penelitian dapat digunakan kuesioner dan untuk memperoleh tanggapan dari konsumen yang masuk dalam sampel yang diteliti. Teknik penarikan sampel dilakukan secara accidental sampling (sampel kebetulan) yaitu mengambil sampel dari pengunjung yang pernah mengunjungi Bual-Bual Cafe.

\section{Perancangan Kuesioner}

Kuesioner merupakan daftar pertanyaan atau pernyataan yang akan digunakan untuk memperoleh data dari sumber secara langsung melaui proses komunikasi atau dengan mengajukan pertanyaan maupun pernyataan.

Penyusunan kuesioner dilakukan untuk memilih pertanyaan-pertanyaan yang akan disajikan dalam kuesioner agar pertanyaanpertanyaan yang diajukan mudah dimengerti. Pada pembuatan kuesioner juga harus dilihat sesuai dengan apa yang diteliti.

Kuesioner sebagai alat pengumpulan data disusun dalam dua bentuk pertanyaan yang bersifat terbuka dan pertanyaan tertutup. Pertanyaan terbuka dimana responden dapat menjawab sesuai yang diinginkan dengan katakata mereka sendiri, sedangkan pertanyaan tertutup dimana peneliti memberikan

\section{Pengolahan Data}

Pada tahap ini dilakukan pengolahan terhadap data-data yang telah dikumpulkan. Adapun pengolahan data yaitu menggunakan regresi linier berganda dengan menggunakan Uji F (uji simultan) dan Uji t (uji parsial), dengan kedua uji ini bisa diketahui pengaruh dari mareketing mix barbasis media sosial terhadap omzet Bual-Bual Cafe dan Variabel marketingmix yang dominan mempengaruhi omzet Bual-Bual Cafe.

\section{Pengolahan Dan Pembahasan}

\section{Analisis Demografi Responden}

Berdasarkan hasil pengolahan data pada bab sebelumnya dapat diketahui bahwa responden berjumlah 100 orang, Teknik penarikan sampel dilakukan secara accidental sampling (sampel kebetulan) yaitu mengambil sampel dari 
pengunjung yang pernah mengunjungi Bual-Bual Cafe dengan jumlah seberapa banyak peneliti membutuhkannya. Dalam penelitian ini peneliti membutuhkan sebanyak 100 responden.

\section{Persamaan Regresi Linier Berganda}

Adapun Persamaan regresinya adalah sebagai berikut :

$\mathrm{Y}=-415.962,016+12.978,874 \mathrm{X}_{1}+9.210,400$

$\mathrm{X}_{2}+9.177,687 \mathrm{X}_{3}+6.595,765 \mathrm{X}_{4}+\mathrm{e}$

Arti angka-angka dalam persamaan regresi diatas:

a. Nilai konstanta (a) sebesar - 415.962,016. Artinya adalah apabila persepsi terhadap produk, tempat, harga dan promsi diasumsikan nol (0), maka omzet sebesar Rp. 415.962,016 atau sama dengan nol (0) karena nilainya negatif.Nilai konstanta (a) sebesar - 415.962,016. Sehingga dapat dijelaskan yaitu sebelum munculnya masingmasing variabel bebas seperti produk, tempat, harga, promosi maka omzet Bual-Bual Cafe mengalami kerugian sebesar Rp.415.962,016 atau Rp.-415.962.061.Karena nilai konstantanya kecil, maka perlunya keempat variabel tersebut untuk meningkatkan omzet Bual-Bual Cafe.

b. Nilai koefisien regresi variabel (X1) "Produk" sebesar 12.978,874. Artinya adalah bahwa setiap peningkatan persepsi terhadap produk sebesar 1 satuan maka akan meningkatkan omzet sebesar Rp. 12.978,874 dan sebaliknya, dengan asumsi variabel lain tetap.

Jika faktor produk ingin mencapai nilai konstanta, faktor produk harus meningkatkan poin sebesar 32 satuan maka peningkatan omzet mejadi 415.962,016. Dapat juga diartikan bahwa jika Bual-Bual Cafe ingin mendapatkan titik impas omzetnya dari faktor produk, maka Bual-Bual Cafe harus memperhatikan bagian produknya baik dari perbaikan terhadap tampilan makanan dan minuman, porsi makanan dan minuman, meningkatkan citra rasa, melengkapi jenis makanan dan minuman dan lain sebagainya. Bahkan faktor produk sangat berpengaruh terhadap konsumen yang akan datang kembali untuk menikmati makanan dan minuman ke Bual-Bual Cafe sehingga dengan banyaknya pengunjung yang datang kembali ke Bual-Bual Cafe maka setiap harinya Bual-Bual Cafe tidak sepi pengunjung dan omzet juga akan mencapai target.

c. Nilai koefisien regresi variabel X2)“Tempat" sebesar 9.210,400. Artinya adalah bahwa setiap peningkatan persepsi terhadap tempat sebesar 1 satuan maka akan meningkatkan omzet sebesar Rp. 9.210,400 dan sebaliknya, dengan asumsi variabel lain tetap.

Jika faktor tempat ingin mencapai nilai kostanta, faktor tempat harus meningkatkan persepsi tempat sebesar 45 satuan maka peningkatan omzet sebesar 415.962,016. Dapat juga diartikan jika Bual-Bual Cafe ingin mencapai titik impas omzetnya dari faktor tempat, maka Bual-Bual Cafe harus melakukan perbaikan terhadap tempat, baik dari segi dekorasi, tempat parkir, dan lain sebagainya. Faktor tempat sangat mempengaruhi daya tarik konsumen untuk mengunjungi Bual-Bual Cafe.

d. Nilai koefisien regresi variabel (X3)“Harga" sebesar 9.177,687. Artinya adalah bahwa setiap peningkatan persepsi terhadap harga sebesar 1 satuan maka akan meningkatkan omzet sebesar Rp. 9.177,687 dan sebaliknya, dengan asumsi variabel lain tetap.

Jika faktor harga ingin mencapat nilai kostanta, faktor harga harus meningkatkan persepsi sebesar 45 satuan dan omzet mengalami peningkatan sebesar 415.962,016. Dapat diartikan bahwa jika Bual-Bual Cafe ingin mencapai titik impas omzetnya dari faktor harga, maka Bual-Bual Cafe harus bisa menentukan harga yang tepat supaya titik impas tercapai dan tidak mendapat keluhan mengenai harga dari konsumen. Dalam hal ini faktor harga juga akan mempengaruhi konsumen dan omzet Bual-Bual Cafe.

e. Nilai koefisien regresi variabel (X4)“Promosi" sebesar 6.595,765. Artinya adalah bahwa setiap peningkatan persepsi terhadap promosi sebesar 1 satuan maka akan meningkatkan omzet sebesar Rp. 6.595,765 dan sebaliknya, dengan asumsi variabel lain tetap.

Jika faktor promosi ingin mencapai nilai kostanta, faktor promosi harus meningkatkan persepsi menjadi 63 satuan dan omzet akan meningkat sebesar 415.962,016. Dapat juga diartikan bahwa jika Bual-Bual Cafe ingin mencapai titik impas omzetnya dari faktor promosi, maka Bual-Bual Cafe harus meningkatkan faktor promosinya. Peningkatan faktor promosi sangat mempengaruhi terhadap omzet Bual-Bual Cafe jika Bual-Bual Cafe meningkatkan promosinya baik dari media sosial seperti facebook, instagram, maka akan banyak masyarakat luas mengetahui Bual-Bual Cafe dan jika Bual-Bual Cafe juga memberikan diskon, hiburan lainnya maka masyarakat akan tertarik dan ingin mencoba mengunjungi Bual-Bual Cafe. 
f. Standar error (e) merupakan variabel acak dan mempunyai distribusi probabilitas yang mewakili semua faktor yang mempunyai pengaruh terhadap $\mathrm{Y}$ tetapi tidak dimasukan dalam persamaan.

\section{Uji Koefisien Determinasi $\left(\mathbf{R}^{2}\right)$}

Untuk mengetahui uji koefesien determinasi dapat dilihat dari tabel dibawah ini :

Tabel 1. Koefisien determinasi

\begin{tabular}{|l|c|r|r|r|}
\hline \multicolumn{5}{|c|}{ Model Summary } \\
\hline Model & $\mathrm{R}$ & $\begin{array}{c}\mathrm{R} \\
\text { Square }\end{array}$ & $\begin{array}{c}\text { Adjusted R } \\
\text { Square }\end{array}$ & $\begin{array}{l}\text { Std. Error of } \\
\text { the Estimate }\end{array}$ \\
\hline 1 & $.821^{\mathrm{a}}$ & .674 & .660 & 48965.67109 \\
\hline
\end{tabular}

Nilai R Square sebesar 0,674. Artinya adalah bahwa persentase pengaruh produk, tempat, harga dan promosi terhadap omzet adalah sebesar $67,4 \%$. Sedangkan sisanya $32,6 \%$ dipengaruhi oleh variabel lain yang tidak dimasukkan dalam model regresi ini.

\section{Kesimpulan Dan Saran}

Setelah dilakukan pengolahan maka didapatkan kesimpulan bahwa pengaruh Marketing Mix berbasis berbasis media sosial terhadap Omzet Bual-Bual Cafe. Jika Bual-Bual Cafe ingin meningkatkan Omzet maka harus memperbaiki variabel 4P yaitu Produk, Harga, Tempat dan Promosi dari Marketing Mix.Dari hasil pengolahan menggunakan Regresi maka variabel dari Marketing Mix yang paling dominan mempengaruhi omzet Bual-Bual Cafe adalah Produk dengan nilai signifikan $(4,614)$ diikuti variabel Harga $(3,065)$, Tempat $(2,452)$ dan Promosi (2,342).

\section{Daftar Pustaka}

[1] Alwi. Kriteria Empirik Dalam Menentukan Ukuran Sampel Pada Pengujian Hipotesis
Statistika Dan Analisis Butir. Jurnal Formatif, Vol 2 No 2 Pendidikan Matematika Universitas Indraprasta PGRI, Jakarta. 2012. Diakses di http://Jurnal.uip.ac.id Pada Tanggal 5 Januari 2017

[2] Assauri, Sofjan. Manajemen Pemasaran (Dasar, Konseo, dan Strategi) Ed. 1,-9.:Rajawali Pers, Jakarta 2017

[3] Cahyono, Penggunaan Facebook sebagai Media pemasaran Online. Jurnal Penelitian Jurusan Manajemen Fakultas Bisnis Universitas Katolik Widya Mandala, Surabaya. 2012. Diakses di http://Jurnal.ac.id pada 4 Februari 2017

[4] Hayani, Manajemen Pemasaran. Suska Prees. Pekanbaru.2012.

[5] Mirratin, Strategi Public Relation Butik Dian Pelangi Dalam Mensosialisasikan Busana Muslim Melalui New Media. Tugas Akhir Komunikasi dan Penyiaran Islam Fakultas Ilmu Dakwah Dan Ilmu Komunikasi UIN Syrif Hidayatullah, Jakarta 2014. Diakses di http://Skripsipenelitian.ac.id pada tanggal 4 Februari 2017

[6] Puryono, Pengaruh Marketing Mix Terhadap Keputusan Pembelian Pada UD Galagah Di Magetan. Jurnal Ilmu dan Riset, Sekolah Tinggi Ilmu ekonomi Indonesia, Surabaya 2014. Diakses di http://Jurnal.stie.ac.id pada tanggal 4 februari 2017

[7] Putra, Analisis Pengaruh Variabel Marketing Mix Terhadap Keputusan Konsumen Dalam Pembelian Cuka Apel Tahesta Studi Kasus PT Tirta Sarana Sukses, Pandaan. Jurnal Penelitian Vol 3. Malang.2014

[8] Puspita K D, Analisis Break Event Point Terhadap Perecanaan Laba PR. Kreatifa Hasta Mandiri. Tugas Akhir Sarjana Ekonomi. Yogyakarta 2012.

[9] Setiawati, Mashuri, Peran Media Sosial Sabagai Upaya Pemasaran Bisnis Online. Jurnal Penelitian, Surabaya. 2013.

[10] Silaen, Widiyono, Metodologi Penelitian Sosial Untuk Penulisan Skripsi dan Tesis. Penerbit IN MEDIA Jakarta 2013. 